ISSN: 2288-2766 @ 2020 EABEA. http://eajbe.jams.or.kr doi: http://dx.doi.org/10.20498/eajbe.2020.8.1.1

\title{
A Study on the Effects of Quality Characteristics of Online Environment-Friendly Agricultural Products Shopping Malls affecting Customer Trust and Purchase Intention
}

\author{
Duk-Gun PARK ${ }^{1}$, Choung-Seob SHIN ${ }^{2}$ \\ 1 First Author Institute of Business Administration Studies, Caroline University, California, America \\ E-mail: ejrrjs1@naver.com \\ 2coreesponding Author Professor, Business School, Caroline University, California, America \\ E-mail: shincsub@korea.kr
}

Received: January 3, 2020. Revised: January 15, 2020. Accepted: February 29, 2020.

\begin{abstract}
Purpose - This study is to classify quality characteristics of online environment-friendly agricultural products shopping malls into 6 categories and to empirically test their relationship with customer trust, perceived manageability, perceived utility and purchase intention.

Research design, data, and methodology - This study targeted adults who have purchased ecofriendly agricultural production online malls for 4 weeks from September 3 to September 30, 2019. The survey type used was a structuralized self-report survey questionnaire made to meet the research purpose in 2019 as the time range. Out of 800 questionnaires, 500 copies are used after excluding surveys with insincere responses.

Results - First, results to hypothesis 1, which was about independent variables and customer trust. Analysis showed that health, familiarity, platform reputation, reviews and product quality were found to have significant effect on customer trust; the hypothesis was adopted. On the other hand, system security did not affect customer trust significantly; it was rejected. Second, customer trust was shown to have significant effect on perceived manageability and perceived utility, so the hypothesis was adopted. Third, the hypothesis that perceived manageability moves onto perceived utility was adopted. Moreover, the hypothesis that perceived manageability moves onto purchase intention and the hypothesis that perceived utility moves onto purchase intention were adopted as well.
\end{abstract}

Conclusions - Furthermore, the results of the study imply that it's imperative for online environment-friendly agricultural products shopping malls to consider their characteristics as the means to increase purchase intention of customers.

Keywords: Environment-friendly agricultural products, Online shopping mall, Customer trust, Technology Acceptance Model

JEL Classification Code: F23, G32. 


\section{Introduction}

As customers' incomes are increasing and living standards are improving, there are growing interests in environment-friendly agricultural products. The reason why Korean customers are interested in environmentfriendly agricultural products is that consumption standards and understanding of fresh agricultural products increased (Ko, 2007). Also, the numbers of stores selling environment-friendly products are growing and their sales are rising due to the efforts of the government and civilian. In order to support for the expansion of distribution and consumption of environment-friendly agricultural products, the government promotes structures for distribution of environment-friendly producing areas. As per $\ulcorner$ Act on the Promotion of Environment-Friendly Agriculture $\lrcorner$, environment-friendly agricultural products and certification on organic processed food are being managed (National Agricultural Products Quality Management Service, 2018).

The environment-friendly agriculture is the agriculture that doesn't excessively use chemical substances such as agricultural chemicals and fertilizers and growth accelerators or doesn't harm human bodies as using organic matters possible to circulate naturally instead of chemical substances and preserving nature ecologies and environments (Jeon, 2001).

Along with the growing interests in environment-friendly agricultural products, a change to distribution environments can be considered as an expansion aspect of environment-friendly agricultural products. Especially, online shopping markets have played important roles in changes to internal and external environments according to developments in information and technologies and have rapidly been growing with the concept of M-Commerce related to mobile markets (Gupta \& Arora, 2017). The online shopping mall means a virtual place for sales where individuals or groups can transact goods or services, using information technology devices like computers (Statistics Korea, 2019). There are few spatial and temporal limitations of customers because they don't search for information or decide to purchase offline. This is the biggest advantage of online shopping malls. Also, online shopping malls can help producers and distributors to secure the price competitiveness by making them reduce costs from operations along with inventory managements and in-store displays including distribution (Ahn, 2006).

However, customers should see products in person and decide to purchase them when they purchase and consume environment-friendly agricultural products, using online shopping malls. There are limitations that they can't do like this. This can be a barrier factor when customers purchase environment-friendly agricultural products, using online shopping malls. In other words, when customers purchase environment-friendly agricultural products in web-based shopping malls, a study is important to remove inconvenience and distrust that they should purchase environment-friendly agricultural products through information and services which online shopping malls provide. Thus, there was a few the study to improve purchase intention during the process that customers purchase environment-friendly agricultural products online although transaction frequency and sales are increasing through online shopping malls. As for previous studies related to environment-friendly agricultural products, Kim (2013) divided customers' selection standards on environment-friendly agricultural products into health and convenience related to purchasing and familiarity through studies on relationships between their selection standards on environment-friendly agricultural products and purchase intention. Ji (2018) conducted a study on quality characteristics of online platform-based food shopping malls. In other words, previous studies related to agricultural products have examined just quality characteristics to improve purchase intention. On the other hand, it was determined that there were few studies on quality characteristics which online shopping malls should provide when customers purchase environment-friendly agricultural products online.

Thus, this study intends to conduct the study on the effects of quality characteristics of online environmentfriendly agricultural products shopping malls affecting customer trust and purchase intention, focusing on a technology acceptance theory. For doing so, this study intends to divide quality characteristics of online environment-friendly agricultural products shopping malls into 6 categories - health and familiarity and platform reputation and reviews and system security and product quality and intends to analyze the effects of purchase intention through customer trust and perceived manageability and perceived utility. Also, this study intends to determine structural relationships with online shopping malls' quality characteristics and customer trust and perceived manageability and perceived utility and purchase intention as analyzing relationships between quality characteristics and purchase intention that online shopping malls should provide when it comes to purchasing environment-friendly agricultural products through online shopping malls. This study intends to contribute to online shopping malls with theoretical evidences practically and provide useful implications. Also, this study can provide theoretical evidences suitable for consumption behaviors to purchase environment-friendly agricultural products in online shopping malls and operation strategies of online shopping malls and alternatives for improvement and practical implications to be helpful for efficient implementation of marketing strategies. 


\section{Theoretical Discussion}

\subsection{Environment-Friendly Agricultural Products}

Korea's environment-friendly agriculture enacted and announced "Act on the Promotion of EnvironmentFriendly Agriculture" on December in 2019. In the same act, environment-friendly agricultural products were defined as the agriculture preserving environments and producing safe agricultural products through compliance with standards on uses of safe agricultural chemicals and the standard amounts of fertilization by crop and appropriate animal feed additives. The government established 'five-year plans for the promotion of the environment-friendly agriculture' and has pushed ahead with five-year policies, starting in 2001. The government is pushing ahead with strategy projects such as improvement in the certification system and establishment of the distribution system and expansion of the consumption and expansion of the production base and safe provision on materials for organic farming by implementing the fourth five-year plans for the promotion of the environmentfriendly agriculture under the vision that was called 'the sustainable environment-friendly agriculture based on national trust' from 2016 to 2020 (Korea Rural Economic Institute, 2018). Environment-friendly agricultural products can be considered as the agriculture method harmonized with the sustainable agriculture and ecological environment. However, they have variously been defined by relevant countries and international organizations or associations because there were no clear and unified regulations and concepts (Lee, 2017). Codex Alimentarius Commission defined the environment-friendly agriculture as the agriculture method using the biological and physical method or the cultivation method opposite to compounds to improve health of the agricultural ecosystem through facilitation of the biological circulation and biological action promotion of soils and diversity of living things (Jeon, 2007). The National Agricultural Products Quality Management Service defined environment-friendly agricultural products as agricultural products (including livestock products) that were produced as not using materials related to chemistry such as synthetic chemicals and chemical fertilizers and antibiotics and antimicrobials and minimizing their uses and maintaining and preserving the agricultural ecosystem and environment through recycling of byproducts of agricultural and ranching and forestry industries. When it comes to the market size of environment-friendly agricultural products, organic and pesticide-free agricultural products have steadily been increasing since the 2000s. The government has expanded about $75 \%$ of their total cultivated area from $4.5 \%$ $(75,000 \mathrm{ha})$ to $8 \%(133,000 \mathrm{ha})$ by 2020 . In 2016, the market size rose to $21 \%$, compared to 2015 because environment-friendly agricultural products' shipments and prices increased (Han, 2019). The Korea Rural Economic Institute analyzed tendencies for the market size by certification and item. The result showed that the market size of environment-friendly agricultural products is predicted to rise by about $5.8 \%$, an annual average since 2018 and is expected to reach the size, 2,136 billion won in 2025 .

Environment-friendly agricultural products have other characteristics different from existing conventional agricultural products. Their characteristics are divided into a product characteristic and price characteristic and market characteristic. The summary is as follows (Kim \& Kim, 2005). First, as for their product characteristic, environment-friendly agricultural products are credence goods to place importance on eco-friendly environment and safety and have the characteristic, information asymmetry. Especially, customers can't check accurate information on functions and utilities of items when they purchase environment-friendly agricultural products and only producers can check accurate information on agricultural products. Thus, information that customers can check are so limitative. Second, as for their price characteristic, environment-friendly agricultural products' distribution structure is different from general agricultural products and is the method to decide prices based on production costs rather than deciding prices from demand and supply. Its operation system from procurement to selling is independent, compared to general agricultural products because prices were decided based on contract cultivation. Customers' demand information on environment-friendly agricultural products can be distorted. Third, as for their market characteristic, environment-friendly agricultural products are being sold through various channels such as living cooperative associations and large distributors and food services and franchises and national agricultural cooperative federations and online shopping malls and face to face sales with customers and school feeding as they are distributed in consumption sites. This has a limitation on negotiations with large distributors or general retail shops, mainstream markets in consumption sites or supplies of stable quantities because mountain district suppliers of environment-friendly agricultural products are not strong.

As for previous studies on environment-friendly agricultural products, Song et al. (2014, 2016) conducted a survey of farm workers and intermediate distributors and retailers and utilized existing research data and conducted a survey on environment-friendly agricultural products' distribution channels and proportions and suggested realistic alternatives such as setting of standard pricing and improvement in trust and arrangement for places for education promotion to activate distribution and consumption. Kim and Jung (2016) promoted the environment-friendly 
agriculture and studied alternatives to strengthen management of agricultural environment and conducted a domestic and foreign field survey and suggested alternatives for activating environment-friendly agricultural products' consumption and distribution such as price adjustment and improvement in the certification system and arrangement for the management system of inedible organic processed food. And Han (2019) provided customers with more effective theoretical evidences than environment-friendly agricultural products through the study on the effects that an image factor had on perceived qualities and perceived values and purchase intention as a thing to decide customers' purchasing behavior factor and suggested useful basic data and marketing strategies that businessmen of the environment-friendly agriculture could utilize.

\subsection{Characteristics of Online Shopping Malls}

Amazon, an online shopping mall was first established by JEFF Bezos, a fund manager of the Wall Street of America on July in 1994. In Korea, Interpark was first opened in 1997 and has been operated (Lee, 2018). Korea has developed its information and communications technology and has increased the number of internet users and the amounts of transactions of online shopping malls along with the innovative growth of the distribution system. As for concepts and definitions of online shopping malls, Hofman\&Novak (1996) said products were advertised and displayed for commercial transactions of the internet in online shopping malls. Products' prices and structures and data on characteristics are included in online shopping malls and information on products was provided through multimedia in web pages. Like this, online shopping malls were defined as an assemblage of online stores including various products.

According to Statistics Korea, as for sales by retail business status in 2018, department store sales was 30 trillion won and their growth trends were slowed down and total sales of large marts reduced by $-1.0 \%$ from the previous year. Main causes were the prolonged low growth and growing competition with other retailers and change to customers' purchasing patterns. As the number of single households and dual income households is growing and non-store retailers' sales are rapidly rising, performances of retail businesses are reducing. However, sales of nonstores such as online malls and TV home shopping exceeded 70 trillion won and distributors are being interested in online industries (Kim, 2018). Online shopping transactions were 113.7296 trillion won, up $30.6 \%$ from the previous year. Mobile shopping transactions among online shopping transactions were 69.949 trillion won, up $30.6 \%$. Home appliances and electronic devices and telecommunication devices rose to $27.2 \%$ and trip and transportation service rose to $10.8 \%$ and food service rose to $93.0 \%$. Every product group increased its transactions and mobile shopping transactions among online shopping transactions accounted for $60 \%$.

The study on characteristics of online shopping malls has been conducted from various viewpoints. Lee (2005) grasped shopping malls' properties that customers preferred based on understanding of their properties to suggest effective retail strategies and analyzed characteristics of purchasing behaviors. Properties of online shopping malls were suggested as follows. First, composing designs and sites and offering photos are included as screen composition and navigation factors. Second, sale coupons or mileages and accumulated money systems and events and product discounts are included as promotion factors. Third, products of famous brands and fame of shopping malls and product warranty and return and refund policy and exchange warranty details are included as trust factors. Fourth, product and price information and assortment of products and various payment methods are included as customer service factors. Fifth, exchange and return and refund are included as customer service factors.

Advantages and disadvantages of online shopping malls are as follows. First, there can be accesses to markets and open information as characteristics of online shopping malls. Online shopping malls are closed less than existing offline or traditional distribution channels. and are more specific in terms of product understanding of purchasers and can give and take much more information. Third, interaction between online shopping malls and customers and DB establishment are easy. This interaction can be considered as the ability to collect and remember responses to communication with customers and needs of customers at the same time (Kim, 2012).

\subsection{Concepts of Customer Trust and Previous Studies}

Customer trust means a standard that customer trust companies as the product of relationship formation established between companies and customers. This is a connected concept that affects situations at perceived risks as customers encounter uncertain and obscure states in terms of their own expected satisfaction based on these consumption experiences and choice situations based on imperfect information.

In previous studies on customer trust, Berry and Parasuraman insisted importance of trust in that customers purchased products at first before experiencing real products or services and said trust was the most important factor to carry out effective service marketing in relationships between companies and customers. Butler (1991) divided 10 
requirements for trust into consistency and utility and capability and fairness and autonomy and loyalty and diligence and openness and acceptability and fulfillment of promises. Heo (2011) supposed the significant effects that relationships between service quality and trust had on company trust and examined the effects that service quality of customer centers had on customer trust and attachment factors in the study. Especially, existing studies that examined factors creating trust online insisted that sizes and reputation of organizations are important factors to have important effects on establishing trust elements (Ganesan, 1994; Doney \& Cannon, 1997; Javenpaa et al, 2000). When sizes of organizations became gradually larger and reputation on organizations became gradually better, customers were accessed that their abilities to deal with risks of organizations were outstanding. Trust in online transactions is defined as a series of beliefs about service providers' sincerity such as honesty or fulfillment of promises (service providers' honesty, fulfillment of promises) and consideration (service providers' interests) and capability (ability offering what customers need) and predictability (consistency of service providers' attitudes). However, customers basically bear burdens on risks of online environment. It's because customers didn't purchase products after experiencing or using real products or services and relied on photos posted on web sites when they decided to purchase products online. Anxiety on commercial transactions on the internet affects itself as an element that threatens product purchasing (Hoffman, Novak \& Peralta, 1999; Lee \& Turban, 2001).

Thus, customer trust should precede all others in order to establish and strengthen relationships with customers and make customers touched and operate consistent transaction relationships (Shin, 2019).

Both companies and customers' efforts are important for customer trust. However, companies which intend to establish customer trust should make progress on strategies for the service discovery from customers by grasping customer needs. Thus, customer trust has the effects on customer loyalty and the positive effects on purchase intention of customers when customer trust becomes gradually higher.

\subsection{Concepts of Purchase Intention and Previous Studies}

Purchase intention means a will revealing behaviors that will happen in the future questioned or planned by individuals. This also means probabilities that beliefs and attitudes of customers lead to purchase intention (Park et al., 2015). Like this, purchase intention can predict consumption behaviors. As a result, it offers important implications on establishment of marketing strategies and demand forecasting. Scholars have used measuring tools of purchase intention to predict customers' behaviors (Engel \& Engel, 1990). In other words, purchase intention means expectations on future behaviors from customers or probabilities that beliefs and attitudes of customers can lead to purchase behaviors. Like this, correlations between purchasing are high because beliefs and attitudes meaning planned future behaviors of customers lead to behaviors (Engel, Balckwell \& Miniard, 1995).

As for previous studies on purchase intention, Lee (2009) examined effect relationships between purchase intention on LOHAS images and environment-friendly agricultural products. The result showed that a LOHAS image factor had the positive effects on purchase intention of environment-friendly agricultural products in the study. Kim (2013) examined the effects that values of environment-friendly consumption had on trust and purchase intention on environment-friendly agricultural products in the study. He set trust as a variable affecting purchase intention. The result showed that customers' purchase intention on environment-friendly agricultural products became high when trust on environment-friendly agricultural products became gradually higher. In other words, this means probabilities leading to purchase behaviors are high when customers' knowledges and trust on environmentfriendly agricultural products become gradually better. Thus, customer education and promotion and production processes that can make customer trust increase should be opened and clarified to create positive purchase intention on environment-friendly agricultural products.

\subsection{Technology Acceptance Model}

A technology acceptance model was developed by Dabis in 1989 and was suggested as a theoretical frame in order to determine factors affecting acceptance attitudes that members have about a new information technology system introduced in the future for improvement in work performances of organizations. The purpose of the technology acceptance model is to find external factors affecting acceptance processes and cause-and-effect relationships with beliefs that members have about specific innovation and attitudes meaning negative assessment and intention to uses and actual uses.

Davis suggested the attitude as the key decision factor that can predict intention using the new information technology system and suggested perceived utility and perceived manageability of uses as decision factors of attitudes assessed as not being materialized by a rational behavior theory. Perceived utility was defined as the extent of trust that work performances could be improved by using the information technology and perceived 
manageability of uses was defined as the extent of trust that uses of the information technology are easy (Davis, 1985; Davis et al., 1989). Perceived utility and perceived manageability affect attitudes of users and attitudes and perceived utility affects behavior intention. Especially, perceived manageability affects perceived utility. It's because users feel that the system is useful when using it becomes gradually easier (Davis et al., 1989).

As for previous studies utilizing the technology acceptance model, studies of Lee et al. (2006) examined users' behaviors as accepting Davis' technology acceptance model and adding security factors in order to analyze spreads of mobile banking uses. It was revealed that security had the significant effects on the utility factor of mobile banking and negative correlations between attitudes. The study analyzed negative recognition on uses happened. It was because usability was low when security became gradually higher.

As for characteristics of users and systems affecting websites' reuses, studies of Lee et al. (2007) verified significance by applying an expansion model of the technology acceptance model. The study results showed that characteristics such as users' functions and technologies and experiences had the significant effects on perceived complexity and the perceived complexity factor had the significant effects on the perceived utility factor and the perceived pleasure factor and the perceived pleasure had the significant effects on website reuses of users. Especially, studies of Nam et al. (2014) analyzed cause-and-effect relationships of the technology acceptance model drawn by the study related to smart phones as setting precedence factors of the technology acceptance model. The study results showed that the biggest effect factor was pleasure in terms of perceived utility. Through this, pleasure that smart phone users felt had the significant effects on utility. Reliability and suitability and self-efficacy also had the effects on perceived utility. This study suggested easy channels and self-efficacy as the most meaningful and effective factor in terms of the perceived use. Like this, they can widely be used in a variety of fields in terms of the introduction of the new technology and system.

\section{Methodology}

\subsection{Research Model}

This study aimed to analyze the quality characteristics of online ecofriendly agricultural product malls on customer trust and purchase intention and designed its research model using Technology Acceptance Model. The study also sought to examine the relationship among purchase intentions in the quality characteristics of online ecofriendly agricultural product malls. The research model is as in $<$ Figure $1>$.

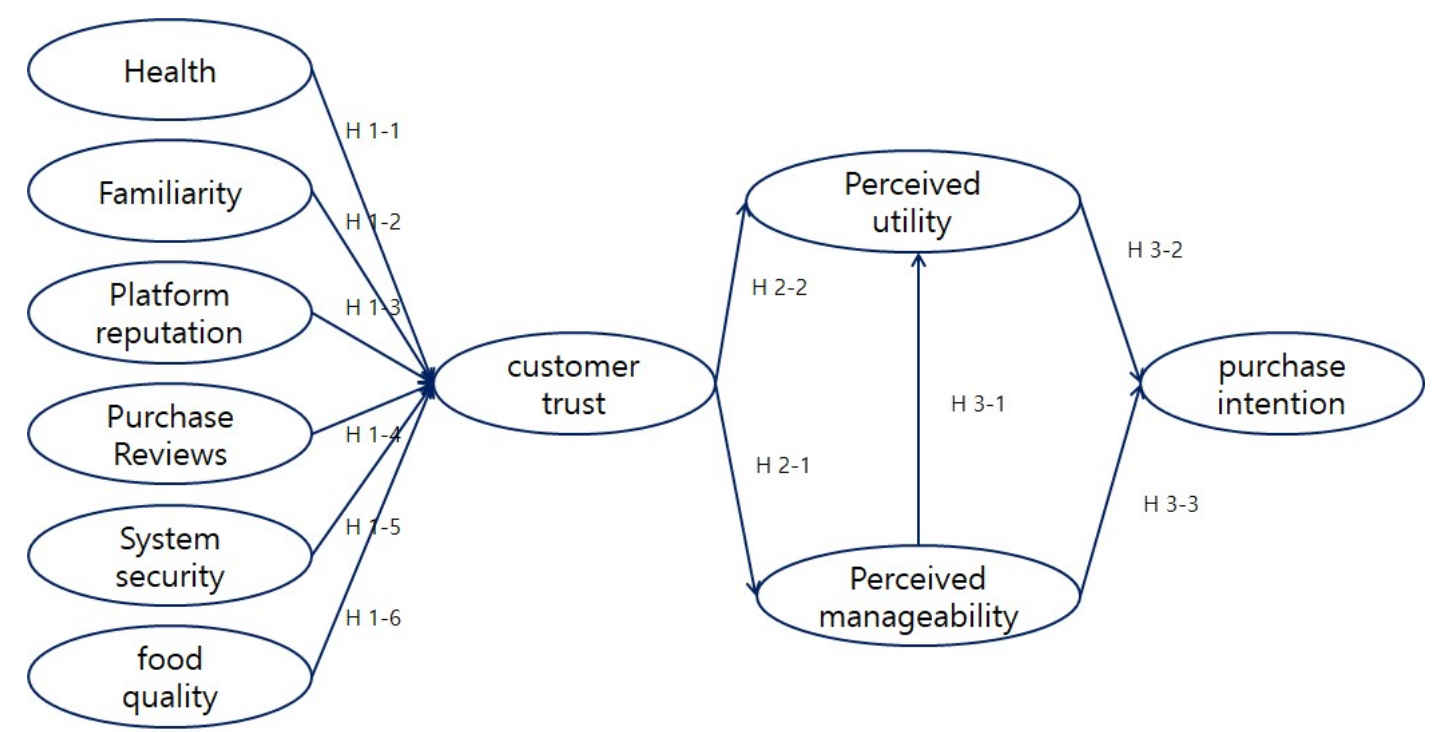

Figure 1: Research model 
To examine the above research model in more detail, the study will first analyze the effects of each sub-factor of the quality characteristics of online ecofriendly agricultural product malls on customer trust. Second, the study will analyze whether customer trust affects perceived manageability and utility, and third, it will analyze the structural relationship structural relationship between perceived manageability and perceived utility extracted from the Technology Acceptance Model and empirically analyze the correlation with purchase intention.

\subsection{Research Hypothesis}

\subsubsection{Relationship between customer trust and the quality characteristics of online ecofriendly agricultural $p$ roduct malls (H 1)}

From the quality characteristics of online ecofriendly agricultural product malls, this study defined health and familiarity as a standard a consumer chose to meet the group or social impact $\mathrm{s} / \mathrm{he}$ follows to choose online ecofriendly agricultural product malls, similar to the choice motivation proposed by Kim (2012) and Park, Lee (2012). Accordingly, the study assumed that health is the degree of awareness that ecofriendly agricultural products are healthier than regular agricultural products, and familiarity as the degree of how often a consumer experience them. Other empirical studies on health (Lockie et al., 2004; Schifferstein \& Oude Ophuis, 1998) and familiarity (Prescott et al., 2002; Rappaport et al., 1992; Steptoe et al., 1995) said health all affected customer trust for the purchase of ecofriendly agricultural products. The following hypotheses were set

H 1-1: Health will have a positive (+) effect on customer trust.

H 1-2: Familiarity will have a positive $(+)$ effect on customer trust.

McKnight et al. (2002) said platform reputation was a determinant to build trust online, and the reputation and fame of a website played a crucial role in members' participation and immersion. Shin (2004)said customer purchase can occur easily if customers purchased products or service online through the sellers' strong reputation. Son (2014) analyzed the effects of reputation, price, manageability, and pleasure on trust and immersion and concluded that reputation and price had a positive $(+)$ effect on trust. The preceding studies confirmed that platform reputation affected customer trust, and the following Hypothesis 1-3 was set.

H 1-3: Platform reputation will have a positive $(+)$ effect on customer trust.

The customer experience of purchasing products or services through online shopping significantly affected the acquisition of various information and purchase through oral activities as well as post-purchase behaviors, which are very significant effects from a company's perspective (Ji, 2018). Also, Lee (2016) examined in her study the effects of the properties of mobile app for fresh food purchase on customer trust and satisfaction and net benefit factor. The results showed that online review shad positive effect on trust and satisfaction as information produced by other users. Purchase Reviews affect trust for customers and the following hypothesis can be set.

H 1-4: Purchase Reviews will have a positive (+) effect on customer trust.

As an important element affecting customer satisfaction, security is the most important and basic element in system quality and is hence used often as a variable in studies on e-commerce and O2O service. Shin and Kim (2015) concluded in their study that since all payments are made on a mobile device in an $\mathrm{O} 2 \mathrm{O}$ service, gaining customer trust on transaction security significantly affected service satisfaction or preference. Likewise, system security affected trust and the following hypothesis $1-5$ is set as below.

H 1-5: System security will have a positive (+) effect on customer trust.

Lee, et al. (2006) demonstrated in their study that the quality and price of food significantly affected trust and customer satisfaction. He analyzed the properties of PB menu products in convenience stores, and suggested the properties of menu and store image as the influencing factors of satisfaction. Their study identified in their results that purchaser's satisfaction with PB products significantly affected repurchase intention and brand trust, and that the quality of PB apples sold in large supermarkets significantly affected brand trust and purchase intention. Based on these, the following hypothesis 1-6can set as below. 
H 1-6: Food quality will have a positive (+) effect on customer trust.

\subsubsection{Relationship among customer trust, perceived manageability, and perceived utility (H2)}

Trust is becoming more important in an online environment because buyers cannot meet with sellers face-to-face, cannot check product quality physically, and the risk perceived by customers to seamlessly process refund and exchange in case of quality issues are higher than those of offline transactions (Cho, 2016; Cheon, 2014). Therefore, experiential values such as valuable and necessary information to customers, product quality, usability, and pleasure increases customer trust for purchase (Lee, 2005; Jeong \& Ku, 2013); the trust of online transactions built this way can overcome perceived risk and lead to continuous purchase (Alshangeeti et al., 2009).

When purchasing agricultural products through e-commerce, excellent product quality increases customer trust for the mall and leads to purchase intention as a result. A study by Lee (2016) argued that information quality had a significant effect on trust and satisfaction when customers purchase fresh food on a mobile app, and especially information from the reviews written by a third party especially had huge effects on building trust. Based on these evidences, the following hypothesis $2-1$ and 2-2can be set.

H2-1: Customer trust will have a positive $(+)$ effect on perceived manageability.

H2-2: Customer trust will have a positive $(+)$ effect on perceived utility.

\subsubsection{Relationship among perceived manageability, perceived utility, and purchase intention (H3)}

In e-commerce, Gefen and Straub (1997) applied the Technology Acceptance theory and examined the effects of perceived manageability and perceived utility on purchase intention, and proved that perceived manageability affected perceived utility as a preceding variable.

It was argued that e-commerce through information system not only provides information and facilitates transaction activities but also realizes seamless communication between sellers and consumers, laying an important foundation for trust-based performance purchase intention that can easily satisfy customer needs and desires (Xu et al, 2004). Also, Lin and $\mathrm{Lu}$ (2000) identified that perceived manageability also affected perceived utility as the preceding variable, and Shin (2008) also proved that perceived manageability directly affected perceived utility. Through the preceding studies of the Technology Acceptance, the study accepted that perceived manageability significantly affected perceived utility and that perceived manageability affected purchase intention in the relationship among perceived manageability, perceived utility, and purchase intention. The study set the following hypothesis 3-1, 3-2, and 3-3as below.

H3-1: Perceived manageability will have a positive (+) effect on perceived utility.

H3-2: Perceived manageability will have a positive $(+)$ effect on purchase intention.

H3-3: Perceived utility will have a positive $(+)$ effect on purchase intention.

\subsection{Data Collection}

This study selected study subjects from the entire country through random sampling, and conducted the study on adults who have purchased ecofriendly agricultural production online malls for 4 weeks from September 3, 2019 to September 30, 2019. Customers who have purchased food more than once in the last 3 months were chosen as the sample, and the researcher conducted the survey through EMBRAIN (www.embrain.co.kr), a professional online survey institution. The survey type used was a structuralized self-report survey questionnaire made to meet the research purpose in 2019 as the time range. A total of 800 questionnaires were distributed and 529 copies were retrieved (retrieval rate: $66.1 \%$ ), and used 500 copies as the data for empirical analysis after excluding surveys with $\mathrm{r}$ insincere responses. Thus, the valid response rate compared to the survey distribution was $62.5 \%$.

\subsection{Survey Composition}

This study used a self-report survey questionnaire to obtain data on the quality characteristics, customer trust, perceived manageability, perceived utility, and purchase intention of online ecofriendly agricultural product malls. The study measured all variables by using the multi-dimensional scale used in the preceding study. Survey respondents could respond from 'Strongly disagree'= Point 1 to 'Strongly agree' $=$ Point 5 , and individuals' opinions on each of the survey questions were measured based on the 5-point Likert scale. The quality 
characteristics of online ecofriendly agricultural product malls consisted of 26 questions, which included 3 questions to measure customer trust, 3 questions to measure perceived utility, 3 questions to measure perceived manageability, and 4 questions to measure purchase intention in the survey questionnaire.

Meanwhile, to identify the demographic characteristics of respondents in addition to survey items related to the research variables, the study used a nominal scale by including purchase experience, purchase frequency, purchase products, certification type, mall type, comparison search, and expenses in the survey items. To confirm whether there were problems in the survey questions before distributing them, the researcher received helped from 3 experts ( $1 \mathrm{PhD}$ holder in management, 1 online mall manager, and 1 marketing specialist. The researcher checked the problems of survey questions and their understandability with their help.

Table 1: Survey questions

\begin{tabular}{|c|c|c|c|c|c|c|}
\hline \multicolumn{3}{|c|}{ Variable name } & $\begin{array}{c}\text { Number of } \\
\text { questions }\end{array}$ & Survey questions & Source & Scale \\
\hline \multirow{5}{*}{$\begin{array}{l}\text { Independent } \\
\text { variables }\end{array}$} & \multirow{5}{*}{$\begin{array}{c}\text { Quality } \\
\text { characteristics }\end{array}$} & Health & 4 & $\begin{array}{l}\text { (1) Choice considering } \\
\text { health } \\
\text { (2) Choice considering } \\
\text { minerals and } \\
\text { vitamins } \\
\text { (3) Choice considering } \\
\text { nutrition } \\
\text { (4) Choice considering } \\
\text { immunity }\end{array}$ & \multirow[t]{2}{*}{$\begin{array}{l}\text { Kim } \\
(2013), \\
\text { Kim } \\
(2012)\end{array}$} & \multirow{5}{*}{$\begin{array}{l}\text { Five-point } \\
\text { Likert scale }\end{array}$} \\
\hline & & Familiarity & 3 & $\begin{array}{l}\text { (1) Choose everyday } \\
\text { food } \\
\text { (2) Choose familiar } \\
\text { food } \\
\text { (3) Choose food eaten } \\
\text { in the past }\end{array}$ & & \\
\hline & & Platform reputation & 5 & $\begin{array}{l}\text { (1) Frequently used by } \\
\text { customer } \\
\text { (2) Evaluated to be } \\
\text { professional } \\
\text { (3) Reliable } \\
\text { (4) Receives positive } \\
\text { evaluation } \\
\text { (5) Has positive } \\
\text { reputation overall }\end{array}$ & $\begin{array}{c}\text { Ji (2018), } \\
\text { McKnight } \\
\text { et al. } \\
(2002)\end{array}$ & \\
\hline & & $\begin{array}{l}\text { Purchase } \\
\text { Reviews }\end{array}$ & 4 & $\begin{array}{l}\text { (1) Satisfied with } \\
\text { product reviews } \\
\text { (2) Product reviews are } \\
\text { reliable } \\
\text { (3) Purchases products } \\
\text { by trusting } \\
\text { (4) Trusts and } \\
\text { recommends } \\
\text { product reviews }\end{array}$ & $\begin{array}{c}\text { Ji (2018), } \\
\text { Lee } \\
(2016)\end{array}$ & \\
\hline & & System security & 4 & $\begin{array}{l}\text { (1) Safe and will not be } \\
\text { leaked } \\
\text { (2) Will not be hacked } \\
\text { by the outside } \\
\text { (3) Protects personal } \\
\text { information well } \\
\text { (4) All transaction } \\
\text { records are stored } \\
\text { perfectly }\end{array}$ & $\begin{array}{c}\text { Ji (2018), } \\
\text { Shin\& } \\
\text { Kim } \\
(2015)\end{array}$ & \\
\hline
\end{tabular}




\begin{tabular}{|c|c|c|c|c|c|c|}
\hline & & Food quality & 6 & $\begin{array}{l}\text { (1)Food quality is } \\
\text { excellent } \\
\text { (2) Information and } \\
\text { product quality is } \\
\text { the same } \\
\text { (3) Provides quality } \\
\text { that meets } \\
\text { expectations } \\
\text { (4) The food sold tastes } \\
\text { good } \\
\text { (5) The food sold is } \\
\text { fresh. } \\
\text { (6) Uses appropriate } \\
\text { containers to } \\
\text { maintain quality }\end{array}$ & $\begin{array}{c}\text { Ji (2018), } \\
\text { Lee } \\
(2006)\end{array}$ & \\
\hline \multirow{3}{*}{$\begin{array}{c}\text { Mediating } \\
\text { variables }\end{array}$} & \multicolumn{2}{|c|}{ Customer trust } & 3 & $\begin{array}{l}\text { (1) Sincerely fulfills } \\
\text { promises with } \\
\text { customers } \\
\text { (2) Can be trusted } \\
\text { (3) Performs } \\
\text { transaction-related } \\
\text { duties with honesty }\end{array}$ & $\begin{array}{l}\text { Kang } \\
(2018)\end{array}$ & $\begin{array}{l}\text { Five-point } \\
\text { Likert scale }\end{array}$ \\
\hline & \multicolumn{2}{|c|}{ Perceived utility } & 3 & $\begin{array}{l}\text { (1)Effective for } \\
\text { purchase } \\
\text { (2)Brings profit to } \\
\text { purchase } \\
\text { (3) Saves money and } \\
\text { time }\end{array}$ & $\begin{array}{l}\text { Crespo et } \\
\text { al. }(2009)\end{array}$ & $\begin{array}{l}\text { Five-point } \\
\text { Likert scale }\end{array}$ \\
\hline & \multicolumn{2}{|c|}{ Perceived manageability } & 3 & $\begin{array}{l}\text { (1) Easy to use } \\
\text { (2) Usage method is } \\
\text { clearly } \\
\text { understandable } \\
\text { (3) Easy to use the mall }\end{array}$ & $\begin{array}{c}\text { Davis et } \\
\text { al. (1989), } \\
\text { Venkatesh } \\
\text { \& Davis } \\
\text { (2000) }\end{array}$ & $\begin{array}{l}\text { Five-point } \\
\text { Likert scale }\end{array}$ \\
\hline $\begin{array}{c}\text { Dependent } \\
\text { variables }\end{array}$ & \multicolumn{2}{|c|}{ Purchase intention } & 4 & $\begin{array}{l}\text { (1) Purchase intention } \\
\text { of ecofriendly } \\
\text { agricultural } \\
\text { products } \\
\text { (2) Repurchase } \\
\text { intention } \\
\text { (3) Revisit if positive } \\
\text { recommendation } \\
\text { (4) Continuous use or } \\
\text { not }\end{array}$ & $\begin{array}{l}\text { Jarvenpaa } \\
\text { et al. } \\
(2000) \\
\text { Kim } \\
(2013)\end{array}$ & $\begin{array}{l}\text { Five-point } \\
\text { Likert scale }\end{array}$ \\
\hline $\begin{array}{c}\text { Control } \\
\text { variables }\end{array}$ & $\begin{array}{l}\text { Demographic } \\
\text { characteristics }\end{array}$ & $\begin{array}{l}\text { Gender, Age, Marital } \\
\text { status, Level of } \\
\text { education, } \\
\text { Occupation, Income, } \\
\text { Region }\end{array}$ & 7 & $\begin{array}{l}\text { (1) Gender } \\
\text { (2) Age } \\
\text { (3) Marital status } \\
\text { (4) Level of education } \\
\text { (5) Occupation } \\
\text { (6) Income } \\
\text { (7) Place of residence }\end{array}$ & $\begin{array}{c}\text { Ji (2018), } \\
\text { Kim } \\
(2012)\end{array}$ & $\begin{array}{l}\text { Nominal } \\
\text { scale }\end{array}$ \\
\hline \multicolumn{3}{|c|}{ Total number of questions } & 46 & & & \\
\hline
\end{tabular}

\subsection{Data Analysis}

The study used SPSS 24.0 and AMOS 21.0 to analyze the data and conducted frequency analysis to review the general characteristics of survey respondents. By conducting a reliability test using Cronbach's $\alpha$ on each question, 
the study examined the predictability and performance accuracy of the questions. The study also carried out explorative factor analysis to verify the validity of measured variables and confirmatory factor analysis between measuring questions and latent variables, and lastly, the study conducted path analysis (AMOS)for hypothesis test.

\section{Results}

\subsection{Demographic Analysis}

The General Characteristics of the Subjects used in this study are shown in $<$ Table $2>$.

Table 2: The General Characteristics of the Respondents

\begin{tabular}{|c|c|c|c|}
\hline \multicolumn{2}{|r|}{ Variables } & $\mathrm{N}$ & $\%$ \\
\hline Gender & $\begin{array}{l}\text { Men } \\
\text { Women }\end{array}$ & $\begin{array}{l}226 \\
274\end{array}$ & $\begin{array}{l}45.2 \\
54.8\end{array}$ \\
\hline Age & $\begin{array}{l}20 \mathrm{~s} \\
30 \mathrm{~s} \\
40 \mathrm{~s} \\
50 \mathrm{~s} \\
60 \mathrm{~s} \\
70 \mathrm{~s} \text { or older }\end{array}$ & $\begin{array}{c}20 \\
76 \\
187 \\
175 \\
175 \\
5 \\
\end{array}$ & $\begin{array}{c}4.4 \\
15.2 \\
37.4 \\
35 \\
7 \\
1 \\
\end{array}$ \\
\hline Marital Status & $\begin{array}{l}\text { Married } \\
\text { Unmarried }\end{array}$ & $\begin{array}{c}423 \\
77\end{array}$ & $\begin{array}{l}84.6 \\
15.4\end{array}$ \\
\hline Level of Education & $\begin{array}{l}\text { Below middle school } \\
\text { High school degree } \\
\text { Technical college degree } \\
\text { Attending or graduated from four year university } \\
\text { Graduate school or higher }\end{array}$ & $\begin{array}{c}3 \\
67 \\
73 \\
229 \\
128\end{array}$ & $\begin{array}{c}0.6 \\
13.4 \\
14.6 \\
45.8 \\
25.6\end{array}$ \\
\hline Occupation & $\begin{array}{l}\text { Office workers } \\
\text { Production } \\
\text { Service } \\
\text { Self-employed people } \\
\text { Professionals } \\
\text { Housewives } \\
\text { Students } \\
\text { Others }\end{array}$ & $\begin{array}{c}140 \\
24 \\
33 \\
69 \\
130 \\
57 \\
8 \\
39\end{array}$ & $\begin{array}{c}28 \\
4.8 \\
6.6 \\
13.8 \\
26 \\
11.4 \\
1.6 \\
7.8\end{array}$ \\
\hline
\end{tabular}

As examined thus far, the general characteristics of research subject showed even distribution when a frequency analysis was conducted by dividing them into gender, age, marital status, level of education, and occupation. Hence, it was confirmed that this study had no issues in the samples and in extracting the general theory through the results.

\subsection{Validity and reliability analysis}

To verify the validity of all factors, explorative factor analysis was conducted. Principle component analysis was used to extract the components of all measuring variables, and Varimax was adopted to simplify factor loading values. The question selection thresholds of this study were as follows: the thresholds were met if KMO value was 0.7 or higher, Eigan value was 1.0 or higher, factor loading value was 0.4 or higher, and the total explanation power was $60 \%$ or higher. (Kim, 2008). After the explorative factor analysis, Cronbach's $\alpha$ coefficient was used to test the reliability of each question in the survey questionnaire. The threshold of reliability level was set at 0.6 . The analysis results demonstrated that KMO exceeded the threshold at .982, the Eigen value exceeded the threshold at 1 , and the total explanation power was $74.1 \%$ and satisfied the threshold of $60 \%$; hence there were no problems in the survey questions. Finally, the factor loading value satisfied the threshold at 0.4 . Validity was confirmed according to the results of explorative factor analysis for measuring variables, and reliability was also confirmed as the reliability level of all factors was 0.6 or higher for all questions. 
Table 3: Validity and reliability analysis

\begin{tabular}{|c|c|c|c|c|c|c|c|c|c|c|c|c|}
\hline \multirow{2}{*}{ Category } & \multirow{2}{*}{ Details } & \multicolumn{10}{|c|}{ Rotated component series } & \multirow[t]{2}{*}{$\begin{array}{l}\text { Reliability } \\
\text { (Cronbach's } \alpha \\
\end{array}$} \\
\hline & & 1 & 2 & 3 & 4 & 5 & 6 & 7 & 8 & 9 & 10 & \\
\hline \multirow{4}{*}{ Health } & Health 1 & .207 & 0.293 & 0.33 & 0.178 & 0.315 & 0.221 & .160 & 0.684 & .043 & .008 & \multirow{4}{*}{0.871} \\
\hline & Health 2 & .117 & 0.29 & 0.158 & 0.328 & 0.194 & 0.147 & .137 & 0.772 & .153 & .234 & \\
\hline & Health 3 & .134 & 0.174 & 0.344 & 0.259 & 0.375 & 0.241 & .152 & 0.615 & .112 & .208 & \\
\hline & Health 4 & .130 & 0.217 & 0.173 & 0.294 & 0.366 & 0.192 & .138 & 0.768 & .049 & .233 & \\
\hline \multirow{3}{*}{ Familiarity } & Familiarity 1 & 0.231 & .157 & 0.27 & 0.187 & 0.23 & 0.072 & .182 & .246 & .269 & 0.845 & \multirow{3}{*}{0.871} \\
\hline & Familiarity 2 & 0.284 & .021 & 0.197 & 0.284 & 0.088 & 0.425 & .240 & .120 & .303 & 0.675 & \\
\hline & Familiarity 3 & 0.299 & -.015 & 0.211 & 0.253 & 0.239 & 0.365 & .303 & .150 & .276 & 0.597 & \\
\hline \multirow{5}{*}{$\begin{array}{l}\text { Platform } \\
\text { reputation }\end{array}$} & $\begin{array}{c}\text { Platform } \\
\text { reputation } 1\end{array}$ & 0.079 & 0.272 & 0.742 & 0.155 & 0.123 & 0.264 & .228 & .184 & .331 & .226 & \multirow{5}{*}{0.905} \\
\hline & $\begin{array}{c}\text { Platform } \\
\text { reputation } 2\end{array}$ & 0.331 & 0.178 & 0.754 & 0.223 & 0.158 & 0.048 & .223 & .260 & .260 & .065 & \\
\hline & $\begin{array}{c}\text { Platform } \\
\text { reputation } 3\end{array}$ & 0.316 & 0.235 & 0.608 & 0.366 & 0.229 & 0.149 & .247 & .186 & .225 & .285 & \\
\hline & $\begin{array}{c}\text { Platform } \\
\text { reputation } 4\end{array}$ & 0.286 & 0.22 & 0.574 & 0.457 & 0.179 & 0.171 & .254 & .280 & .264 & .206 & \\
\hline & $\begin{array}{c}\text { Platform } \\
\text { reputation } 5\end{array}$ & 0.294 & 0.286 & 0.58 & 0.435 & 0.178 & 0.136 & .278 & .271 & .240 & .271 & \\
\hline \multirow{4}{*}{$\begin{array}{l}\text { Purchase } \\
\text { reviews }\end{array}$} & Reviews 1 & 0.224 & 0.219 & 0.404 & 0.641 & 0.226 & 0.226 & .269 & .309 & .235 & .342 & \multirow{4}{*}{0.907} \\
\hline & Reviews 2 & 0.302 & 0.246 & 0.339 & 0.651 & 0.266 & 0.152 & .297 & .400 & .229 & .331 & \\
\hline & Reviews 3 & 0.294 & 0.306 & 0.297 & 0.668 & 0.241 & 0.158 & .315 & .387 & .232 & .249 & \\
\hline & Reviews 4 & 0.325 & 0.238 & 0.202 & 0.67 & 0.257 & 0.165 & .270 & .357 & .295 & .356 & \\
\hline \multirow{4}{*}{$\begin{array}{l}\text { System } \\
\text { security }\end{array}$} & Security1 & 0.227 & 0.086 & 0.272 & 0.191 & 0.232 & 0.842 & .265 & .192 & .200 & .228 & \multirow{4}{*}{0.927} \\
\hline & Security2 & 0.282 & 0.432 & 0.203 & 0.291 & 0.097 & 0.668 & .188 & .234 & .200 & .277 & \\
\hline & Security 3 & 0.226 & 0.25 & 0.247 & 0.226 & 0.252 & 0.695 & .191 & .247 & .205 & .273 & \\
\hline & Security4 & 0.325 & 0.341 & 0.224 & 0.177 & 0.202 & 0.598 & .254 & .230 & .211 & .207 & \\
\hline \multirow{6}{*}{$\begin{array}{l}\text { Food } \\
\text { quality }\end{array}$} & $\begin{array}{c}\text { Food } \\
\text { condition } 1\end{array}$ & 0.318 & 0.295 & 0.33 & 0.182 & 0.682 & 0.22 & .180 & .259 & .291 & .164 & \multirow{6}{*}{0.93} \\
\hline & $\begin{array}{c}\text { Food } \\
\text { condition } 2\end{array}$ & 0.203 & 0.293 & 0.162 & 0.327 & 0.773 & 0.145 & .160 & .181 & .146 & .190 & \\
\hline & $\begin{array}{c}\text { Food } \\
\text { condition } 3\end{array}$ & 0.37 & 0.181 & 0.345 & 0.258 & 0.623 & 0.249 & .173 & .162 & .221 & .262 & \\
\hline & $\begin{array}{c}\text { Food } \\
\text { condition } 4\end{array}$ & 0.372 & 0.215 & 0.174 & 0.301 & 0.763 & 0.193 & .276 & .168 & .114 & .120 & \\
\hline & $\begin{array}{c}\text { Food } \\
\text { condition } 5\end{array}$ & 0.356 & 0.304 & 0.309 & 0.297 & 0.499 & 0.039 & .186 & .176 & .239 & .197 & \\
\hline & $\begin{array}{c}\text { Food } \\
\text { condition } 6\end{array}$ & 0.272 & 0.294 & 0.429 & 0.186 & 0.514 & 0.238 & .247 & .183 & .235 & .224 & \\
\hline \multirow{3}{*}{$\begin{array}{c}\text { Customer } \\
\text { trust }\end{array}$} & $\begin{array}{c}\text { Customer } \\
\text { trust } 1\end{array}$ & 0.763 & .192 & .250 & .190 & .055 & .167 & 0.298 & 0.353 & .214 & 0.251 & \multirow{3}{*}{0.911} \\
\hline & $\begin{array}{c}\text { Customer } \\
\text { trust } 2\end{array}$ & 0.758 & .259 & .249 & .208 & .062 & .177 & 0.347 & 0.329 & .205 & 0.241 & \\
\hline & $\begin{array}{c}\text { Customer } \\
\text { trust } 3\end{array}$ & 0.757 & .273 & .212 & .263 & .027 & .106 & 0.311 & 0.26 & .180 & 0.31 & \\
\hline \multirow{3}{*}{$\begin{array}{l}\text { Perceived } \\
\text { utility }\end{array}$} & $\begin{array}{c}\text { Perceived } \\
\text { utility } 1\end{array}$ & .216 & 0.693 & .111 & .189 & .192 & .084 & 0.369 & 0.315 & 0.346 & .159 & \multirow{3}{*}{0.842} \\
\hline & $\begin{array}{c}\text { Perceived } \\
\text { utility2 }\end{array}$ & .271 & 0.817 & .087 & .068 & .212 & -.024 & 0.279 & 0.248 & 0.291 & .239 & \\
\hline & $\begin{array}{c}\text { Perceived } \\
\text { utility3 }\end{array}$ & .119 & 0.562 & .204 & .081 & .130 & .156 & 0.317 & 0.328 & 0.265 & .102 & \\
\hline $\begin{array}{l}\text { Perceived } \\
\text { manageabi }\end{array}$ & $\begin{array}{c}\text { Perceived } \\
\text { manageabilit }\end{array}$ & .283 & .077 & .168 & .186 & .196 & .213 & 0.287 & 0.26 & 0.804 & 0.193 & 0.908 \\
\hline
\end{tabular}




\begin{tabular}{|c|c|c|c|c|c|c|c|c|c|c|c|c|}
\hline \multirow[t]{3}{*}{ lity } & y 1 & & & & & & & & & & & \\
\hline & $\begin{array}{c}\text { Perceived } \\
\text { manageabilit } \\
\text { y } 2\end{array}$ & .205 & .046 & .191 & .151 & .188 & .240 & 0.358 & 0.301 & 0.757 & 0.206 & \\
\hline & $\begin{array}{c}\text { Perceived } \\
\text { manageabilit } \\
\text { y } 3\end{array}$ & .220 & .119 & .201 & .084 & .167 & .237 & 0.289 & 0.295 & 0.782 & 0.237 & \\
\hline \multirow{4}{*}{$\begin{array}{l}\text { Purchase } \\
\text { intention }\end{array}$} & $\begin{array}{l}\text { Purchase } \\
\text { intention } 1\end{array}$ & .110 & .186 & .188 & .188 & .205 & .063 & 0.696 & 0.361 & 0.299 & 0.346 & \multirow{4}{*}{0.929} \\
\hline & $\begin{array}{c}\text { Purchase } \\
\text { intention } 2\end{array}$ & .078 & .197 & .109 & .231 & .155 & .054 & 0.766 & 0.298 & 0.262 & 0.324 & \\
\hline & $\begin{array}{l}\text { Purchase } \\
\text { intention3 }\end{array}$ & .102 & .230 & .165 & .144 & .138 & .103 & 0.731 & 0.357 & 0.323 & 0.185 & \\
\hline & $\begin{array}{l}\text { Purchase } \\
\text { intention4 }\end{array}$ & .117 & .217 & .180 & .238 & .103 & .120 & 0.739 & 0.345 & 0.353 & 0.226 & \\
\hline \multicolumn{2}{|c|}{ Eigenvalue } & 8.807 & 7.132 & 5.990 & 4.936 & 4.103 & 4.011 & 3.740 & 3.375 & 2.844 & 1.976 & \\
\hline \multicolumn{2}{|c|}{$\%$ distribution } & 14.205 & 11.503 & 9.662 & 7.961 & 6.618 & 6.469 & 6.033 & 5.443 & 4.588 & 1.574 & \\
\hline \multicolumn{2}{|c|}{$\begin{array}{c}\text { Total explanation power } \\
\text { (\%) }\end{array}$} & 14.205 & 25.708 & 35.370 & 43.331 & 49.948 & 56.417 & 62.450 & 67.893 & 72.481 & 74.055 & \\
\hline \multicolumn{13}{|c|}{ KMO (.982), Significance probability $(.000)$} \\
\hline
\end{tabular}

\subsection{Confirmatory Factor Analysis}

After conducting explorative factor analysis for validity test, this study performed a confirmatory factor analysis using AMOS 21 for more rigorous validity test and model analysis. The results showed that the Standardization factor loading values were all above 0.5 , and the overall goodness of fit of the model was $\chi^{2}=742.405$, GFI (.874), AGFI (.85 1), RMSEA (.048), NFI (.89 1) and TLI (.944), and CFI (.949), showing that the goodness of the fit is decent as it is close to or satisfies the threshold. The study also verified that it secured concept validity based on more than 0.5 of threshold loading value; that all sub-variables of concept reliability exceeded the threshold of 0.7 with the value of health being the lowest at 0.778; and that Average Variance Extracted (AVE) also exceeded the threshold of 0.5 with health being the lowest at 0.532 . Hence, the study determined that it acquired the convergent validity of this research model.

Table 4: Results of confirmatory factor analysis

\begin{tabular}{|c|c|c|c|c|c|c|c|c|c|}
\hline \multicolumn{3}{|c|}{ Category } & $\begin{array}{c}\text { Non- } \\
\text { standardization }\end{array}$ & Standardization & S.E. & C.R. & $\mathrm{P}$ & $\begin{array}{l}\text { Concept } \\
\text { reliability }\end{array}$ & AVE \\
\hline \multirow{4}{*}{ Health } & $\rightarrow$ & Health 4 & 1 & 0.784 & & & & \multirow{4}{*}{.778} & \multirow{4}{*}{.532} \\
\hline & $\rightarrow$ & Health 3 & 1.092 & 0.811 & 0.047 & 23.208 & $* * *$ & & \\
\hline & $\rightarrow$ & Health 2 & 1.077 & 0.789 & 0.048 & 22.537 & $* * *$ & & \\
\hline & $\rightarrow$ & Health 1 & 1.241 & 0.934 & 0.045 & 27.596 & $* * *$ & & \\
\hline \multirow{3}{*}{ Familiarity } & $\rightarrow$ & Familiarity 3 & 1 & 0.737 & & & & \multirow{3}{*}{.906} & \multirow{3}{*}{.618} \\
\hline & $\rightarrow$ & Familiarity 2 & 1.418 & 0.962 & 0.059 & 24.069 & $* * *$ & & \\
\hline & $\rightarrow$ & Familiarity 1 & 1.072 & 0.789 & 0.055 & 19.418 & $* * *$ & & \\
\hline \multirow{5}{*}{$\begin{array}{l}\text { Platform } \\
\text { reputation }\end{array}$} & $\rightarrow$ & Platform reputation 4 & 1 & 0.842 & & & & \multirow{5}{*}{.930} & \multirow{5}{*}{.626} \\
\hline & $\rightarrow$ & Platform reputation 3 & 1.017 & 0.846 & 0.043 & 23.622 & $* * *$ & & \\
\hline & $\rightarrow$ & Platform reputation 2 & 0.989 & 0.793 & 0.046 & 21.318 & *** & & \\
\hline & $\rightarrow$ & Platform reputation 1 & 0.861 & 0.707 & 0.048 & 18.033 & $* * *$ & & \\
\hline & $\rightarrow$ & Platform reputation 5 & 0.984 & 0.855 & 0.041 & 24.022 & $* * *$ & & \\
\hline \multirow{4}{*}{$\begin{array}{l}\text { Purchase } \\
\text { reviews }\end{array}$} & $\rightarrow$ & Reviews 4 & 1 & 0.8 & & & & \multirow{4}{*}{.874} & \multirow{4}{*}{.641} \\
\hline & $\rightarrow$ & Reviews 3 & 0.975 & 0.87 & 0.043 & 22.705 & $* * *$ & & \\
\hline & $\rightarrow$ & Reviews 2 & 0.976 & 0.869 & 0.043 & 22.684 & $* * *$ & & \\
\hline & $\rightarrow$ & Reviews 1 & 0.906 & 0.842 & 0.042 & 21.697 & $* * *$ & & \\
\hline System & $\rightarrow$ & Security 4 & 1 & 0.678 & & & & .938 & .655 \\
\hline
\end{tabular}




\begin{tabular}{|c|c|c|c|c|c|c|c|c|c|}
\hline \multirow[t]{3}{*}{ Security } & $\rightarrow$ & Security 3 & 0.972 & 0.551 & 0.077 & 12.618 & $* * *$ & & \\
\hline & $\rightarrow$ & Security 2 & 1.469 & 0.963 & 0.071 & 20.75 & $* * *$ & & \\
\hline & $\rightarrow$ & Security 1 & 1.146 & 0.815 & 0.064 & 18.032 & $* * *$ & & \\
\hline \multirow{6}{*}{ Food quality } & $\rightarrow$ & Food condition 4 & 1 & 0.825 & & & & \multirow{6}{*}{.872} & \multirow{6}{*}{.634} \\
\hline & $\rightarrow$ & Food condition 3 & 1.1 & 0.856 & 0.042 & 26.389 & $* * *$ & & \\
\hline & $\rightarrow$ & Food condition 2 & 1.095 & 0.844 & 0.042 & 25.815 & \multirow{2}{*}{$* * *$} & & \\
\hline & $\rightarrow$ & Food condition 1 & 1.202 & 0.951 & 0.038 & 31.339 & & & \\
\hline & $\rightarrow$ & Food condition 5 & 0.662 & 0.554 & 0.042 & 15.808 & $* * *$ & & \\
\hline & $\rightarrow$ & Food condition 6 & 0.615 & 0.508 & 0.043 & 14.476 & $* * *$ & & \\
\hline \multirow{3}{*}{ Customer trust } & $\rightarrow$ & Customer trust 1 & 1 & 0.891 & & & & \multirow{3}{*}{.917} & \multirow{3}{*}{.787} \\
\hline & $\rightarrow$ & Customer trust 2 & 1.008 & 0.899 & 0.034 & 29.619 & $* * *$ & & \\
\hline & $\rightarrow$ & Customer trust 3 & 0.964 & 0.849 & 0.037 & 26.326 & $* * *$ & & \\
\hline \multirow{3}{*}{$\begin{array}{l}\text { Perceived } \\
\text { Utility }\end{array}$} & $\rightarrow$ & Perceived utility 1 & 1 & 0.859 & & & & \multirow{3}{*}{.812} & \multirow{3}{*}{.648} \\
\hline & $\rightarrow$ & Perceived utility 2 & 0.989 & 0.793 & 0.045 & 21.917 & $* * *$ & & \\
\hline & $\rightarrow$ & Perceived utility 3 & 0.879 & 0.763 & 0.043 & 20.629 & $* * *$ & & \\
\hline \multirow{3}{*}{$\begin{array}{c}\text { Perceived } \\
\text { manageability }\end{array}$} & $\rightarrow$ & $\begin{array}{c}\text { Perceived } \\
\text { manageability } 1\end{array}$ & 1 & 0.85 & & & & \multirow{3}{*}{.867} & \multirow{3}{*}{.579} \\
\hline & $\rightarrow$ & $\begin{array}{c}\text { Perceived } \\
\text { manageability } 2\end{array}$ & 1.004 & 0.896 & 0.038 & 26.222 & $* * *$ & & \\
\hline & $\rightarrow$ & $\begin{array}{c}\text { Perceived } \\
\text { manageability } 3\end{array}$ & 1.002 & 0.884 & 0.039 & 25.638 & $* * *$ & & \\
\hline \multirow{4}{*}{$\begin{array}{l}\text { Purchase } \\
\text { intention }\end{array}$} & $\rightarrow$ & Purchase intention 1 & 1 & 0.891 & & & & \multirow{4}{*}{.904} & \multirow{4}{*}{697} \\
\hline & $\rightarrow$ & Purchase intention 2 & 0.961 & 0.88 & 0.033 & 28.716 & $* * *$ & & \\
\hline & $\rightarrow$ & Purchase intention 3 & 0.91 & 0.842 & 0.035 & 26.195 & $* * *$ & & \\
\hline & $\rightarrow$ & Purchase intention 4 & 0.99 & 0.886 & 0.034 & 29.156 & $* * *$ & & \\
\hline \multicolumn{10}{|c|}{$\chi^{2}=742.405, \mathrm{p}=.000, \mathrm{CMIN} / \mathrm{DF}=1.772, \operatorname{GFI}(.874), \operatorname{AGFI}(.85$ 1), RMSEA (.048), NFI (.89 1) and TLI (.944), CFI (.949) } \\
\hline
\end{tabular}

Next, the analysis results confirmed that the discriminant validity (AVE value)was greater than the (correlation coefficient $)^{2}$ value. Since it was confirmed that 1 was not included in the addition or subtraction of correlation coefficient to the standard error multiplied by 2 , there was discriminant validity on correlations among the variables used in this study. Also, the bootstrapping result showed that all values were statistically significant $(\mathrm{p}<.01)$. The results are shown in $\langle$ Table $4>$.

Table 5: Results of determinant validity analysis

\begin{tabular}{|c|c|c|c|c|c|c|c|c|c|c|c|}
\hline Category & 1 & 2 & 3 & 4 & 5 & 6 & 7 & 8 & 9 & 10 & AVE \\
\hline Health & 1 & & & & & & & & & \\
\hline Familiarity & $0.366^{* *}$ & 1 & & & & & & & & & \\
\hline $\begin{array}{c}\text { Platform } \\
\text { reputation }\end{array}$ & $0.449^{* *}$ & $\begin{array}{c}0.423^{* *} \\
*\end{array}$ & 1 & & & & & & & & \\
\hline $\begin{array}{c}\text { Purchase } \\
\text { reviews }\end{array}$ & $0.288^{* *}$ & $0.329^{* *}$ & $.190^{* *}$ & 1 & & & & & & \\
\hline $\begin{array}{c}\text { System } \\
\text { security }\end{array}$ & $0.22^{* *}$ & $0.398^{* *}$ & $.168^{* *}$ & $.418^{* *}$ & 1 & & & & & .626 \\
\hline $\begin{array}{c}\text { Food } \\
\text { quality }\end{array}$ & $0.212^{* *}$ & $0.323^{* *}$ & $.177^{* *}$ & $.435^{* *}$ & $.236^{* *}$ & 1 & & & & & .655 \\
\hline $\begin{array}{c}\text { Customer } \\
\text { trust }\end{array}$ & $0.451^{* *}$ & $0.43^{*}$ & $.209^{* *}$ & $.348^{* *}$ & $.348^{* *}$ & $.497^{* *}$ & 1 & & & .634 \\
\hline $\begin{array}{c}\text { Perceived } \\
\text { utility }\end{array}$ & $0.390^{* *}$ & $0.463^{* *}$ & $.152^{* *}$ & $.136^{*}$ & $.458^{* * *}$ & $.412^{* *}$ & $0.229^{* *}$ & 1 & & .787 \\
\hline $\begin{array}{c}\text { Perceived } \\
\text { manageability }\end{array}$ & $0.403^{* *}$ & $0.322^{* *}$ & $0.349^{* *}$ & $.369^{* *}$ & $.471^{* *}$ & $.213^{*}$ & $0.241^{*}$ & $0.293^{* *}$ & & 1 & .648 \\
\hline $\begin{array}{c}\text { Purchase } \\
\text { intention }\end{array}$ & $0.403^{* *}$ & $.113^{* *}$ & $0.503^{* *}$ & $.512^{* *}$ & $.168^{* *}$ & $.197^{* *}$ & $0.339^{* * *}$ & $.267^{* *}$ & $235^{* *}$ & 1 & .697 \\
\hline
\end{tabular}




\subsection{Hypothesis Test}

Before interpreting the results of path analysis for this research model, this study confirmed the goodness of fit for the model, which was GFI (.864), AGFI (.843), RASEA (.048), NFI (.921), NNFI (.957), CFI (.957) that neared or satisfied the threshold. The results of path analysis for the result models are shown in $<$ Table $5>$ below to confirm whether the hypothesis was adopted, which are determined by looking at $t$ values: C.R and $p$. This study determines that hypothesis is adopted with trust level $95 \%(\mathrm{p}<.05)$ as the threshold which means that C.R must be greater than 1.96.

To examine the path used in this study model, only the path of security leading to customer trust had a significant probability of 0.05 or higher, showing that the path was not significant. In other words, all hypotheses were adopted but hypothesis H 1-5 where system security led to customer trust.

Table 6: Summary of hypothesis test

\begin{tabular}{|c|c|c|c|c|c|c|c|c|}
\hline Category & $\begin{array}{c}\text { Independent } \\
\text { variables }\end{array}$ & $\begin{array}{c}\text { Dependent } \\
\text { variables }\end{array}$ & $\begin{array}{c}\text { Non- } \\
\text { standardization }\end{array}$ & Standardization & S.E. & C.R. & P & Result \\
\hline H 1-1 & Health & $\begin{array}{c}\text { Customer_ } \\
\text { trust }\end{array}$ & 0.172 & 0.151 & 0.029 & 6.025 & $* * *$ & Adopted \\
\hline H 1-2 & Familiarity & $\begin{array}{c}\text { Customer_ } \\
\text { Trust }\end{array}$ & 0.151 & 0.125 & 0.05 & 3.025 & $0.002 * *$ & Adopted \\
\hline H 1-3 & $\begin{array}{c}\text { Platform } \\
\text { reputation }\end{array}$ & $\begin{array}{c}\text { Customer_ } \\
\text { trust }\end{array}$ & 0.254 & 0.244 & 0.075 & 3.366 & $* * *$ & Adopted \\
\hline H 1-4 & $\begin{array}{c}\text { Purchase } \\
\text { reviews }\end{array}$ & $\begin{array}{c}\text { Customer_ } \\
\text { Trust }\end{array}$ & 0.244 & 0.259 & 0.074 & 3.31 & $* * *$ & Adopted \\
\hline H 1-5 & $\begin{array}{c}\text { System } \\
\text { security }\end{array}$ & $\begin{array}{c}\text { Customer_ } \\
\text { trust }\end{array}$ & 0.063 & 0.051 & 0.053 & 1.209 & 0.227 & Rejected \\
\hline H 1-6 & Food_quality & $\begin{array}{c}\text { Customer_ } \\
\text { Trust }\end{array}$ & 0.164 & 0.152 & 0.034 & 4.767 & $* * *$ & Adopted \\
\hline H2-1 & Customer_trust & $\begin{array}{c}\text { Perceived_ } \\
\text { manageability }\end{array}$ & 0.825 & 0.832 & 0.042 & 19.529 & $* * *$ & Adopted \\
\hline H2-2 & Customer_trust & $\begin{array}{c}\text { Perceived_ } \\
\text { Utility }\end{array}$ & 0.767 & 0.741 & 0.062 & 12.273 & $* * *$ & Adopted \\
\hline H3-1 & $\begin{array}{c}\text { Perceived_- } \\
\text { manageability }\end{array}$ & $\begin{array}{c}\text { Perceived_ } \\
\text { Utility }\end{array}$ & 0.242 & 0.232 & 0.059 & 4.09 & $* * *$ & Adopted \\
\hline H3-2 & Perceived_utility & $\begin{array}{c}\text { Purchase_ } \\
\text { Intention }\end{array}$ & 0.717 & 0.731 & 0.067 & 10.73 & $* * *$ & Adopted \\
\hline H3-3 & $\begin{array}{c}\text { Perceived } \\
\text { manageability }\end{array}$ & $\begin{array}{c}\text { Purchase_ } \\
\text { Intention }\end{array}$ & 0.224 & 0.219 & 0.065 & 3.42 & $* * *$ & Adopted \\
\hline X $2=1494.895$, p=.000, CMIN/DF=2.095, GFI (.864), AGFI (.843), RASEA (.048), NFI (.921), NNFI (.957), CFI (.957) \\
\hline
\end{tabular}

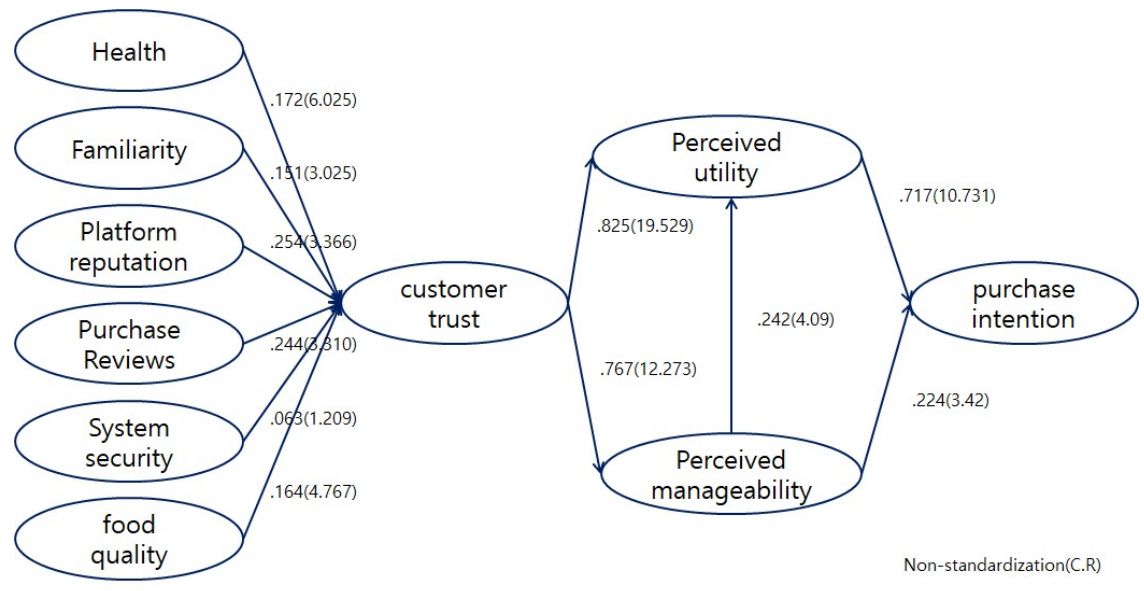

Figure 2: Summary of path analysis 


\section{Conclusion}

\subsection{Summary of Study Results}

The purpose of this study was to categorize online mall for ecofriendly agricultural products into quality characteristics health, familiarity, platform reputation, reviews, system security, and product quality. It also sought to empirically define the relationship among customer trust, perceived manageability, perceived utility, and purchase intention.

The study results can be summarized as follows based on the hypotheses established.

The first is the testing results of hypothesis 1 on the relationship between independent variables and customer trust. The results showed that health $(\mathrm{H} 1-1)$, familiarity $(\mathrm{H} 1-2)$, platform reputation $(\mathrm{H} 1-3)$, purchase reviews (H 14), and food quality (H 1-6) had a significant effect on customer trust, and thus these sub-hypotheses adopted; however, system security (H 1-5) did not have a significant effect on customer trust and was rejected. This means that setting a high quality of health, familiarity, platform reputation, purchase reviews, and food provided to customers for online ecofriendly agricultural product malls increased customer trust. However, strengthening system security among the characteristics of online ecofriendly agricultural product malls means that it did not have a significant effect on customer trust. Health and familiarity, the selection standard of ecofriendly agricultural products in this study results, partially corresponded with the study results of Kim (2013) who examined purchase intention in online malls and hence supported the preceding study. Platform reputation had the same results in this study and in the study of Son (2014)who concluded that reputation had a positive (+) effect on customer trust, and the results for purchase reviews were similar as the study results of Hong et al. (2010) who concluded that purchase reviews had positive effects on customer trust and satisfaction. Also, the results on product quality were similar as Ji (2018)'s study results that food quality had the greatest effect on customer satisfaction in the path with food trust, which showed that this study is consistent with the preceding researchers. However, the result that strengthening security did not significantly affected trust is contrary to Ji (2018)'s study results. This reflects a not significant results that if online malls adopt excessive security policy when customers are trying to make a payment, signup, or encrypt their password, the customers will tend to avoid the online trust and not trust them.

The second is the study results of hypothesis 2 which is on customer trust and perceived manageability, and utility. Customer trust (H2-1) had a significant effect on perceived manageability so the hypothesis was adopted and Customer trust (H2-2) had a significant effect on perceived utility so the hypothesis was adopted. This implies that the higher the customer trust towards malls is, the higher the manageability and utility are. This study result is similar to Ji-won Kang (2018)'s study result that perceived manageability and utility of food O2O service have positive $(+)$ effect on customer trust, thus supporting the preceding study. It is also consistent with the study results of Nam (2017) and $\mathrm{Ku}$, et al (2009) who tested the influence of the perceived manageability and customer trust of mobile technology.

The third is the study results of hypothesis 3 on the relationship among perceived manageability, utility, and purchase intention. The hypothesis (H3-1) that perceived manageability led to utility was adopted, and the hypotheses that perceived manageability led to purchase intention (H3-2) and that perceived utility led to purchase intention (H3-3) was adopted. This means that if customers feel that it is easy to purchase ecofriendly agricultural products online, his or her purchase intention increases. This study result support the Technology Acceptance Model presented by Davis (1985). Another result showed that satisfaction increased if more the customers of online malls perceive that there are practical values in online shopping. This study is supported by the result that if more customers perceive online shopping is practical and economical, they make more purchases online (Lee\& Hong, 2006).

\subsection{Study Implications}

The useful academic implications of this study are as follows.

First, this study proposed six characteristics of online ecofriendly agricultural product malls as health, familiarity, platform reputation, reviews, system security, and product quality and identified the factors that these characteristics affected customer trust. This study is also significant because this study extracted the quality characteristics of online ecofriendly agricultural product malls and set them as the foundation for a follow-up study through an empirical analysis, thereby confirming causality in purchase intention. Second, this study was conducted on Korean ecofriendly agricultural products, which were barely researched in the existing Technology Acceptance Model, and 
confirmed the differences or similarities from the existing Technology Acceptance Model, contributing to its expansion from a new perspective. By applying the characteristics of online ecofriendly agricultural product malls and conceptualizing them theoretically, this study empirically demonstrated that the Technology Acceptance Model is appropriate for the effects on customer trust and purchase intention, having another significance. Third, this study proposes another academic implication as it identified that if customer trust increases for consumers to purchase ecofriendly agricultural products on online malls, purchase intention increases through utility and manageability. Therefore, this study has theoretical significance as it defined the concepts of ecofriendly agricultural products and online malls and researched the subjects from various comprehensive perspectives rather than individual perspectives based on online ecofriendly agricultural product malls operate on site; it drew results by examining and analyzing characteristics.

In addition, the practical implications of this study for management perspective are as follows.

First, this study confirmed that improving health increases customer purchase intention based on customer trust from the perspective of an online mall company. This implies that to improve health, it is the necessary to establish and execute a marketing strategy for an online mall manager or producers of ecofriendly agricultural products to provide various health information and promotions, such as the efficacy or nutrients of ecofriendly agricultural products, that will enable customers to be healthier through selection and purchase.

Second, the study confirmed that if familiarity is strengthened, customers' tendency to purchase ecofriendly agricultural products through online malls based on the stronger trust. Since the consumption level of ecofriendly agricultural products is determined by customer trust, it is necessary to strengthen familiarity by providing correct information on ecofriendly agricultural products to customers, such as the cultivation, production, harvest, distribution, and consumption of ecofriendly agricultural products, to resolve consumer distrust.

Third, the study confirmed that enhancing platform reputation on online malls increases customers' purchase intention based on customer trust. To raise their platform reputation, numerous online malls compete with each other and strive to preemptively gain advantage in platform reputation, by making bold promotions and investments such as impressing customers through various marketing strategies and storytelling, partnerships with related organizations, MOU, CI change, M\&A, and differentiations in products or delivery. Thus, as a means to increase customers' purchase intention in online ecofriendly agricultural product malls, platform reputation becomes a foundation to build a strong network business model and to generate social values and the core engine of service economy, implying that companies should continuously strive to manage and maintain image performance.

Fourth, the study confirmed that customers' tendency to purchase ecofriendly agricultural products through online malls based on customer trust increases. In online malls, reviews are one method of viral marketing as customers who have actually experienced the products or services post them, hence making purchase review management important. Online mall companies that manufacture or sell products use purchase review marketing to be more competitor through customers' word of mouth. As a result, it is necessary to build and manage online review contents for customers to voluntarily participate beyond mere purchase and sales as a place of mutual communication.

Fifth, the study confirmed that strengthening product quality among the characteristics of online ecofriendly agricultural malls increased customers' purchase intention based on customer trust. The characteristics of product quality in online malls can be the basis that customers can make a rational choice in an asymmetric purchase situation with divided products. Thus, as customers make a purchase from online malls by only looking at pictures, the skills of detailed online page expressing price $\leq$ quality. Accordingly, it is important to continuously manage product quality that requires safety management until the final consumption end, due to the concerns of product quality caused by spoiling or germ infection during production, distribution, sales, and delivery.

Sixth, the study confirmed that strengthening system security did not improve customer trust in online malls for ecofriendly agricultural products. Since system security is essential in online transaction and online security is becoming stricter throughout the world and has reached a certain level, it does not have significant effects on customer trust. This implies that online mall owners should pay more attention to other factors affecting trust.

\subsection{Limitations and Proposals}

This study has the following limitations, despite its significance and differentiation due to the use of Technology Acceptance Model to research ecofriendly agricultural products that have not been researched before. The first one is the limitation of this study sample. The study conducted an analysis on the results of 500 survey questionnaires, but it cannot limit the entire population. Thus, it is necessary to acquire many more samples to conduct a study in the future. Second, this study did not present results by the types of online malls through ecofriendly agricultural products. Thus, it is hoped that more realistic proposal is made by presenting results according to the types of online 
malls in the follow-up study. Third, this study did not present the results by the types of customers purchasing ecofriendly agricultural products on online malls, but examined the differences among the results of each factor by analyzing the differences according to demographic characteristics. It is hoped that the follow-up study examines mediating effects according to customer types or various other characteristics.

\section{Reference}

Alshangeeti, A. M., Al-Saghier, H. M., \& Nguyen, A. (2009). Faculty perceptions of attributes affecting the diffusion of online learning in Saudi Arabia: A quantitative study. Proceedings of the international conference on e-learning, 10-24.

Bae, J. M., \& Lee, C. S. (2018). Suggestions for Korea's corporate image, product image, and purchase intention with consumer hostility: focusing on Korean Wave and satisfaction variables. East Asian Journal of Business Economics, 6(4), 25-34.

Berry, L. L., \& Parasuraman, A. (1991). Marketing services: competing through quality. New York: FreePress.

Cheon, D. H. (2014). A study on the relationship among website reputation, perceived risk, trust, and purchase intention in an online travel business. Tourism Study, 28(6), 21-39.

Cho, M. N. (2016). The effects of social commerce characteristics on perceived risk, trust, and repurchase intention: focusing on dining products. Tourism Leisure Study, 28(11), 285-304.

Davis, F. D., Bagozzi, R. P., \& Warshaw, P. R. (1989). User acceptance of computer technology: a comparison of two theoretical models. Management science, 35(8), 982-1003.

Doney, P. M., \& Cannon, J. P. (1997). An examination of the nature of trust in buyer-seller relationships. Journal of marketing, 61(2), 35-51.

Ganesan, S. (1994). Determinants of long-term orientation in buyer-seller relationships. Journal of marketing, $58(2), 1-19$.

Gefen,D., \& Straub, D. W. (1997). Gender differences in the perception and use of e-mail: an extension to the technology acceptance model. MIS Quarterly, 21(4), 389-400.

Gupta, A., \& Arora, N. (2017). Understanding determinants and barriers of mobile shopping adoption using behavioral reasoning theory. Journal of Retailing and Consumer Services, 36(1), 1-7.

Hoffman, D. L., \& Novak, t. P. (1996). Marketing in hypermedia computer-mediated environments: Conceptual foundations. Journal of marketing, 60(3), 50-68.

Hoffman, D. L., Novak, t. P., \& Peralta, M. (1999). Building on Trust Online. Communications of the ACM, 42 (4), 80-85.

Hwang, Y. C. (2013). A study on customer satisfaction and post-purchase behavior on online shopping of agricultural products in Jeju Area. Marketing Journal, 21(2), 59-71.

Jeon, T. G. (200 1). Problems and improvement plans of the distribution of ecofriendly agricultural products. Food Distribution Study, 18(1), 73-95.

Jeong, B. C., \& Ku, J. O. (2013). The effects of the characteristics of SNS delivers and SNS information on purchase intention. Corporate Management Study, 48(1), 251-272.

Kim, D. H. (2018). Distribution trend of market environment. New Agro-food New Marketing Institute New Distribution Focus, 2(1), 19-12.

Kim, D. S. (2013). The effects of ecofriendly consumption value on the trust and purchase intention of ecofriendly agricultural products. Korean Culinary Society, 19(1), 103-120.

Kim, M., \& Lee, T, J. (2009). The effects of LOHAS image on the purchase intention of ecofriendly agricultural products. Journal of Korean Food Service Association, 5(1), 153-171.

Korea Rural Economic Institute (2018). Korea rural economic institute (2019). Retrieved August 30, 2019, from http://www.krei.re.kr

Lee, E. J., \& Hong, B. S. (2006). The effects of perceived practical value and service quality on fashion product repurchase intension in internet shopping. Bokshik, 56(7), 46-57. 
Lee, E. Y. (2016). The effects of the characteristics of mobile Apps for fresh food purchase on customer trust, satisfaction, and net benefit. e-Business Study, 17(4), 175-192.

Lee, E. Y., Jeong, S. K., \& Lee, S. B. (2006). The effects of instant messenger App on communication ffficiency in the travel industry. Tourism Leisure Study, 18(3), 63-82.

Lee, J. M. (2019). The relationships among brand assets, customer satisfaction, brand trust, and brand loyalty related to golf products. East Asian Journal of Business Economics, 7(3), 75-81.

Lee, K. Y. (2005). A study on the immersion of online community users: focusing on the relationship among trust, attitude, and immersion. Industry Economic Research, 18(1), 119-142.

Lee, M. K., \& Turban, E. (2001). A trust model for consumer internet shopping. International Journal of electronic commerce, 6(1), 75-91.

Lee, M. Y. (2005). The effects of attribute perception and shopping values of online clothing malls on purchase behaviors. Journal of the Korean Association of Human Ecology, 14(1), 155-165.

Lee, W. W., Park, J. H., \& Hong, Y. G. (2007). A study on user and system characteristics that effect website reuse. Management Information Study, 21(1), 131-154.

Lee,D. H., Kwak, S. H., \& Hwang, K. S. (2006). A study on the differences in using internet and mobile banking using technology acceptance model. Technology Innovation Study, 14(1), 201-225.

Lin, J. C., \& Lu, H. (2000). Towards an understanding of the behavioral intention to use a web site. International Journal of Information Management, 20(2), 197-208.

Lockie, S., Lyons, K., Lawrence, G., \& Grice, J. (2004). Choosing organics: a path analysis of factors underlying the selection of organic food among Australian consumers. Appetite, 43(1), 135-146.

Morgan, R. M., \& Hunt, S. D. (1994). The commitment-trust theory of relationship marketing. Journal of marketing, 58 (3), 20-38.

Nam, S. T., Shin, S. Y., \& Jin, C. Y. (2014). A literature review and meta analysis on the preceding factors of technology acceptance model. Journal of Korea Institute of Information Communication, 18(4), 848-854.

Park, J. Y., \& Lee, S. G (2012). A study on the tourism motivation of tourists in Gyeongju region and to attract revisitors. Tourism Study, 27(3), 163-179.

Rappaport, L., Peters, G., Huff-Corzine, L., \& Downey, R. (1992). Reasons for eating: an exploratory cognitive analysis. Ecology of Food and Nutrition, 28(1), 171- 189.

Shin, J. K., \& Lee, S. Y. (2017). The effects of the delivery service quality of online fresh food shopping malls on Esatisfaction and repurchase intention of online customers. East Asian Journal of Business Economics, 6(2), 14-27

Shin, J. K., Lee, S. Y. (2019). A study on the effect of online activation business transaction factors of fresh food shopping mall on e-customer relationship quality and e-customer loyalty. East Asian Journal of Business Economics, 7(1), 1-16.

Shin, S. W. (2008). A study on the effects of customers' shopping value and perceived trust on re-purchase intention through an airline company website. Tourism Research, 23(2), 157-184

Son, J. G. (2014). Factors affecting the acceptance intention and recommendation intention of social commerce and online malls. Journal of Korea Contents Association, 14(3), 352-360.

Steptoe, A., Pollard, t. M., \& Wardle, J. (1995), Development of a measure of the motives underlying the selection of food: the food choice questionnaire. Appetite, 25(1), 267-284.

Umunnakwe, C., \& Kim, G. B. (2019). The impact of service quality, satisfaction, trust on customer loyalty for mobile operators in Nigeria. East Asian Journal of Business Economics, 7(2), 31-41. 